University of Nebraska - Lincoln

DigitalCommons@University of Nebraska - Lincoln

Agronomy \& Horticulture -- Faculty Publications

Agronomy and Horticulture Department

2004

\title{
Old-Field Grassland Successional Dynamics Following Cessation of Chronic Disturbance
}

\author{
Susan Tunnell \\ University of Nebraska-Lincoln \\ David Engle \\ Oklahoma State University, david.engle@okstate.edu \\ Eric Jorgensen \\ United States Environmental Protection Agency
}

Follow this and additional works at: https://digitalcommons.unl.edu/agronomyfacpub

Part of the Plant Sciences Commons

Tunnell, Susan; Engle, David; and Jorgensen, Eric, "Old-Field Grassland Successional Dynamics Following Cessation of Chronic Disturbance" (2004). Agronomy \& Horticulture -- Faculty Publications. 223. https://digitalcommons.unl.edu/agronomyfacpub/223

This Article is brought to you for free and open access by the Agronomy and Horticulture Department at DigitalCommons@University of Nebraska - Lincoln. It has been accepted for inclusion in Agronomy \& Horticulture -Faculty Publications by an authorized administrator of DigitalCommons@University of Nebraska - Lincoln. 


\title{
Old-field grassland successional dynamics following cessation of chronic disturbance
}

\author{
Tunnell, Susan J. ${ }^{1,2 *}$; Engle, David M. ${ }^{1,3}$ \& Jorgensen, Eric E. ${ }^{4}$ \\ ${ }^{1}$ Department of Plant and Soil Sciences, Oklahoma State University, Stillwater, OK 74078, USA; ${ }^{2}$ Current address: Depart- \\ ment of Agronomy and Horticulture, University of Nebraska-Lincoln, P.O. Box 830915, Lincoln, NE 68583, USA; ${ }^{3}$ E-mail \\ dme@mail.pss.okstate.edu; ${ }^{4}$ United States Environmental Protection Agency, Office of Research and Development, National \\ Risk Management Research Laboratory, P.O. Box 1198, Ada, OK 74820,USA; E-mail jorgensen.eric@epa.gov; \\ *Corresponding author; Fax+14024727904; E-mail stunnell2@unl.edu
}

\begin{abstract}
.
Question: Does increasing Festuca canopy cover reduce plant species richness and, therefore, alter plant community composition and the relationship of litter to species richness in old-field grassland?

Location: Southeastern Oklahoma, USA.

Methods: Canopy cover by species, species richness, and litter mass were collected within an old-field grassland site on $16,40 \mathrm{~m} \times 40 \mathrm{~m}$ plots. Our study was conducted during the first three years of a long-term study that investigated the effects of low-level nitrogen enrichment and small mammal herbivory manipulations.

Results: Succession was altered by an increase in abundance of Festuca over the 3-yr study period. Species richness did not decline with litter accumulation. Instead, Festuca increased most on species-poor plots, and Festuca abundance remained low on species-rich plots.

Conclusions: Festuca may act as an invasive transformerspecies in warm-season dominated old-field grasslands, a phenomenon associated more with invasions of cool-season grasses at higher latitudes in North America.
\end{abstract}

Keywords: Festuca arundinacea; Heavy grazing; Redundancy Analysis (RDA); Species richness.

Nomenclature: Anon. (1986).

\section{Introduction}

Grazing is a keystone disturbance that shaped the development and maintenance of the North American tallgrass prairie (Knapp et al. 1998). In temperate mesic grasslands dominated by native warm-season grasses, disturbance by grazing maintains species richness through its influence on succession and resource availability (Collins 1987; Collins \& Steinauer 1998; Smith \& Knapp 1999). Large herbivores continually influence vegetation structure and community composition through defoliation and trampling of vegetation (Collins \& Steinauer 1998). Secondary succession in both native and old-field (cultivated then abandoned) grasslands after removal of heavy grazing usually results in an increase in late-successional warm-season grasses (Freeman 1998; Engle et al. 2000), an increase in litter accumulation that decreases species richness (Collins 1987; Carson \& Peterson 1990; Foster \& Gross 1998), and a decrease in abundance of non-dominant grasses and forbs (Weaver 1968; Knapp et al. 1998).

However, the presence of exotic species may alter the usual secondary succession in old-field grasslands following grazing removal (Tremmel \& Peterson 1983; Fike \& Niering 1999). In much of North America, Festuca arundinacea is an invasive perennial grass that is native to Eurasia (Gibson \& Newman 2001). Its superior competitive ability conferred by an endophytic fungal symbiont (Clay 1990; Bacon 1995; Clay \& Holah 1999; Matthews \& Clay 2001) may lead to its dominance in native and old-field grasslands and thereby alter species composition (Clay \& Holah 1999) and nutrient cycling (Gay et al. 1996).

The widespread use of Festuca for forage, turf, and soil conservation purposes began in the 1940s, and Festuca gained status as a commonly planted species in the eastern US (Ball et al. 1993; Hoveland 1993). Although Festuca is considered by pastoralists to be a valuable forage species in planted pastures, native and old-field grasslands lacking disturbance may be at risk of Festuca invasion, which can result in Festuca becoming a transformer species as defined by Richardson et al. (2000). Studies of Festuca have focused on the effects of species richness and plant-soil interactions of endophyte-infected Festuca (Clay \& Holah 1999; Matthews \& Clay 2001). These studies were primarily concerned with the difference between endophyte-infected and uninfected Festuca in monocultures and simple mixtures, rather than the overall effect of relatively small amounts of Festuca in natural grasslands. 
We assumed that Festuca alters vegetation dynamics and succession in warm-season old-field grasslands released from heavy grazing. Our objective was to describe vegetation dynamics in an old-field grassland released from chronic heavy grazing, dominated by warm-season grasses, and invaded by Festuca. We predicted that increasing Festuca would reduce species richness and therefore alter plant community composition and the relationship of litter to species richness. If this prediction were to hold and Festuca were to have clear ecosystem impacts, then Festuca would fit the designation of an invasivetransformer species (Richardson et al. 2000). Our study was conducted in the first three years of a long-term study that investigated the effects of low-level nitrogen enrichment and small mammal herbivory manipulations.

\section{Methods}

This study was conducted in southeastern Oklahoma at the Center for Subsurface and Ecological Assessment Research (CSEAR), operated by the US EPA, R.S. Kerr Environmental Research Center (Ada, OK). Cultivation at the site was abandoned around 1950. Herbaceous vegetation naturally re-established, and during the last half century the old-field grassland was grazed on a continuous basis until January 1998. Dominant vegetation consisted of early to mid-successional grasses and forbs including Aristida oligantha, Andropogon virginicus, Ambrosia psilostachya, and Aster ericoides. There were also exotic species present including Festuca arundinacea and Cynodon dactylon. The predominant soil type is Burleson clay (fine, montmorillonitic, thermic, Udic Pellusterts) (Anon. 1973). Annual precipitation is 990 $\mathrm{mm}$, which predominantly occurs from April through October (Anon. 2000).

This old-field grassland has been the focus of an interdisciplinary study in which 16 plots of $40 \mathrm{~m} \times 40 \mathrm{~m}$ received a factorial arrangement of nitrogen and small mammal herbivory exclusion treatments. Nitrogen was applied in the form of $34 \% \mathrm{NH}_{4} \mathrm{NO}_{3} 4 \times$ during the year (February, May, August, and November) with a total of $16.3 \mathrm{~kg}-\mathrm{N} \cdot \mathrm{ha}^{-1} \cdot \mathrm{yr}^{-1}$. Small mammal herbivory was manipulated using $2.5 \mathrm{~cm}$ chain-link fence ca. $2 \mathrm{~m}$ in height. The treatments included (1) no nitrogen and no fence; (2) nitrogen and no fence; (3) no nitrogen and fence; (4) nitrogen and fence. To determine if species composition varied among treatments, we performed Redundancy Analysis (RDA) using CANOCO version 4 (ter Braak \& Šmilauer 1998). To test for a nitrogen effect on canopy cover, nitrogen was the explanatory variable and fence was the covariable. To test for a fence effect, fence was used as the explanatory variable and nitrogen was a covariable. Because no treatment effects were detected for nitrogen $(P=0.46)$ or fence $(P=0.14)$, we performed all subsequent analyses at the plot level without regard to treatment.

We sampled $250.1-\mathrm{m}^{2}$ quadrats in herbaceous vegetation in May 1999, 2000, and 2001 for canopy cover and species richness. Canopy cover was estimated by species with the Daubenmire (1959) cover class method, and analysed by functional group. The grass and sedge functional groups were based on photosynthetic pathway and origin and included (1) cool-season native grasses; (2) Festuca arundinacea - a cool-season introduced grass; (3) warm-season native grasses, and (4) warm-season introduced grasses; (Waller \& Lewis 1979; Hatch \& Pluhar 1993; Stubbendieck et al. 1997). Forbs were separated by nitrogen fixing ability into non-legume forbs and legumes (Anon. 1986). Analyses of non-legume forbs were at both the species and functional group level. Species richness was determined through an extensive search of species present in the entire plot. Litter was harvested from five 0.1- $\mathrm{m}^{2}$ quadrats per plot in August 1998,1999 , and 2000 . Litter mass was dried at $60^{\circ} \mathrm{C}$ in a forced-air oven until reaching a constant weight.

We calculated average quadrat canopy cover $(n=25)$ for each species by plot in 1999, 2000, and 2001. To investigate community composition, we performed an RDA on the species data with Festuca as the explanatory variable. We also examined relationships between Festuca canopy cover and functional group canopy cover using Pearson's correlation coefficients $(r)$.

To test our prediction that Festuca would alter the relationship of species richness to litter accumulation, we used regression analysis (Anon. 1991) to examine relationships among (1) species richness and litter mass and (2) species richness and Festuca cover. To determine if a plot's composition and species richness changed as Festuca increased, or alternatively to determine if Festuca increased on plots with respect to a plot's composition or richness, we calculated a Jaccard Similarity Index (Jongman et al. 1995) as follows,

$S_{J}=c /(a+b+c)$

where, $a=$ the number of unique species in a plot in 1999 , $b=$ the number of unique species in a plot in 2001, and $c$ $=$ the number of species shared by the plot in 1999 and 2001. A similarity index of 1.0 would indicate no change in species presence over time, whereas a similarity index of zero would indicate a complete change in species presence over time. We then used correlation to determine if a change in Festuca canopy cover was accompanied by a change in species presence of plots. 


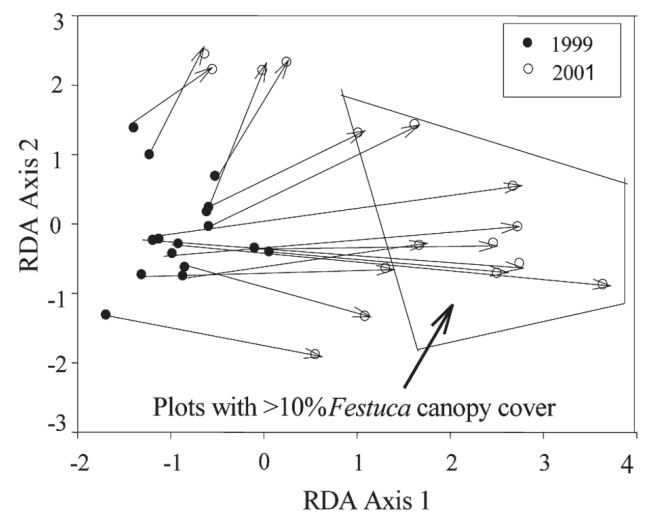

Fig. 1. Site scores for axes 1 and 2 of the Redundancy Analysis following grazing removal in an old-field grassland from 1999 (O) to 2001 (O). Axis 1 is represented by increasing Festuca canopy cover and has an eigenvalue of $0.135(P=0.01)$.

\section{Results}

Vegetation dynamics were explained by increasing abundance of Festuca. The change in species composition within plots is visually represented in the ordination diagram in which plots with the greatest amount of Festuca (>10\% canopy cover) are located in the right half of the diagram (Fig. 1). Festuca cover increased nearly fivefold on average across plots from 1999 to 2001 (Table 1), which is reflected along RDA Axis 1.

Festuca was correlated with the two dominant functional groups, warm-season native grasses and non-legume forbs that represented most of the species and total canopy cover (75\% in 1999). Warm-season native grass cover was not correlated with Festuca cover in the first two growing seasons (1999: $P=0.13,2000: P=0.77)$ when Festuca cover was less, but by 2001 Festuca canopy cover was correlated negatively $(P<0.01, r=-0.71)$ with warm-season native grass cover. However, plots with the greatest warm-season native grass cover (e.g. 28\%) had the smallest amount of Festuca cover (e.g. 0.7\%) in 2001 , and plots with low warm-season native grass canopy cover (e.g. 6.9\%) had the greatest amount of Festuca cover (e.g. 21.9\%). The relationship appears to be causal in that, on the average, warm-season native grasses decreased most on plots where Festuca increased most (Fig. 2).

Table 1. Mean and standard error (SE) of species richness and Festuca canopy cover in an Oklahoma old-field grassland ( $n$ $=16$ ).

\begin{tabular}{ccccc}
\hline & \multicolumn{2}{c}{ Species richness } & \multicolumn{2}{c}{ Festuca canopy cover (\%) } \\
Year & Mean & SE & Mean & SE \\
\hline 1999 & 44 & \pm 2 & 2.3 & \pm 0.6 \\
2000 & 37 & \pm 1 & 4.9 & \pm 1.0 \\
2001 & 41 & \pm 2 & 10.9 & \pm 2.0 \\
\hline
\end{tabular}

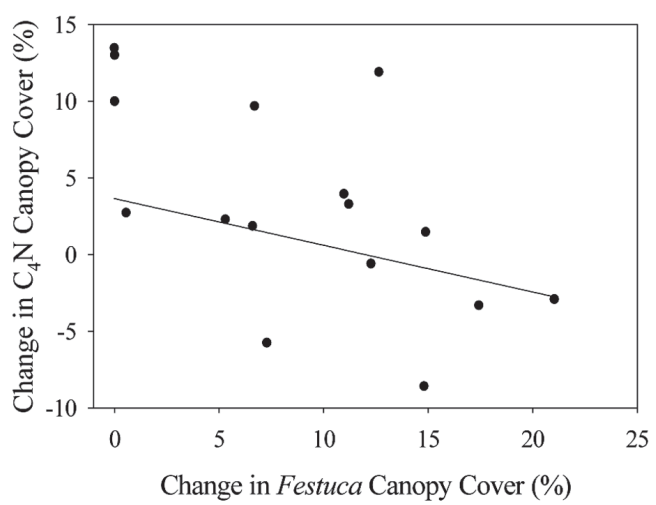

Fig. 2. Plot of the correlation between the change in Festuca canopy cover and the change in warm-season native canopy cover from 1999 to $2001(P=0.04 ; r=-0.56)$.

The dominance of two abundant non-legume forbs determined the overall influence of Festuca on the nonlegume forb functional group. Non-legume forb cover was positively correlated ( $P=0.03, r=0.53$ ) to Festuca canopy cover in 1999 when mean Festuca cover was $2.3 \%$. But with greater Festuca canopy cover in 2000 and 2001, non-legume forb canopy cover and Festuca canopy
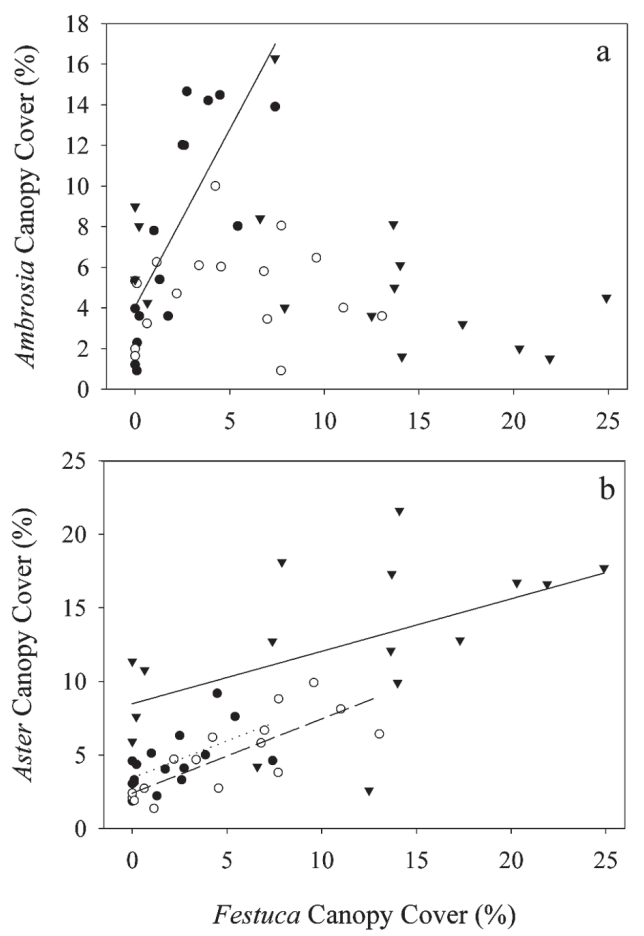

Fig. 3a. Correlation between Festuca and Ambrosia canopy cover in $(\bullet) 1999(P<0.01, r=0.80)$; (O) $2000(P=0.74)$ and ( $\mathbf{\nabla}) 2001(P=0.07)$. b. Correlation between Festuca canopy cover and Aster canopy cover, $1999(P=0.02 ; r=0.59), 2000$ $(P<0.01 ; r=0.80)$, and $2001(P=0.03 ; r=0.53)$. 

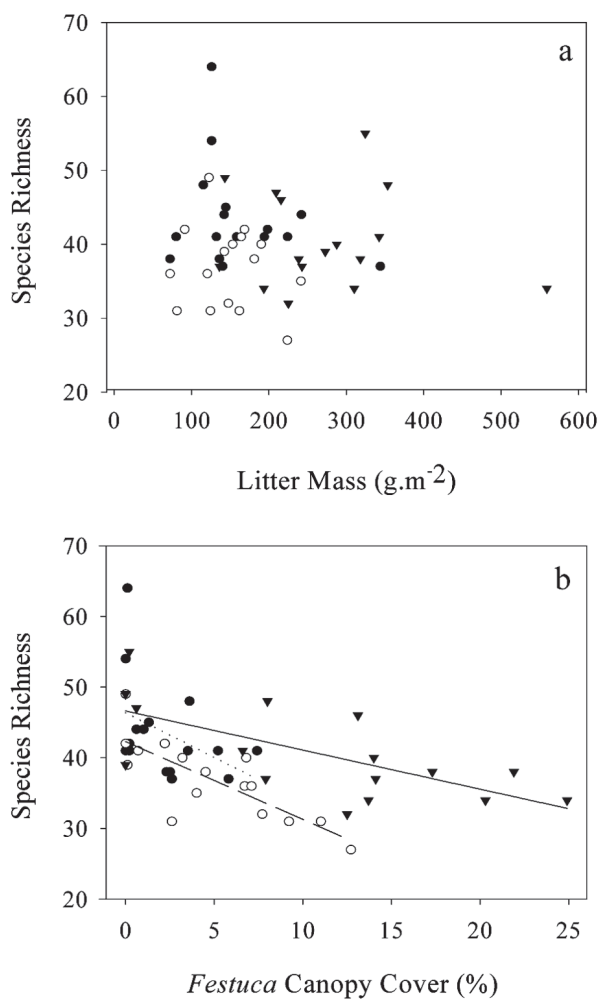

Fig. 4a. Species richness as a function of litter mass. Regression models were not significant in $(\bigcirc) 1999(P=0.36)$; (O) $2000(P=0.56)$ and $(\boldsymbol{\nabla}) 2001(P=0.69)$. b. Species richness $Y$ as a function of Festuca cover $X$. Regression model for 1999 not significant $(P=0.11)$; for 2000 significant $(P<0.01)$, with $Y=42.3-1.1 X, r^{2}=0.62$; for 2001 significant $(P<0.01)$, with $Y=46.6-0.5535 X, r^{2}=0.46$.

cover were not correlated $(P>0.1)$. Ambrosia canopy cover, which accounted for $20 \%$ of the non-legume forb canopy cover in 2001, was positively correlated with Festuca canopy cover in 1999 (Fig. 3a), but not in 2000 or 2001. Plots in which Festuca canopy cover was greatest, Ambrosia abundance was low. Aster canopy cover, which accounted for $44 \%$ of the non-legume forb canopy cover in 2001, was positively correlated with Festuca canopy cover in all three years (Fig. 3b). Aster canopy cover increased from 1999 to 2001 and was the most abundant non-legume forb in 2001. The loss of canopy cover contributed by minor non-legume forb species was accounted for by an increase in Aster canopy cover.

Species richness was not correlated to litter mass (Fig. 4a), but species richness was negatively related to Festuca canopy cover (Fig. 4b). However, the change in Festuca canopy cover was not correlated with the change in the total number of species from 1999 to 2001 (Fig. 5a). Furthermore, Festuca canopy cover increased on plots that were both similar and dissimilar in species presence from 1999 to 2001 (Fig. 5b).
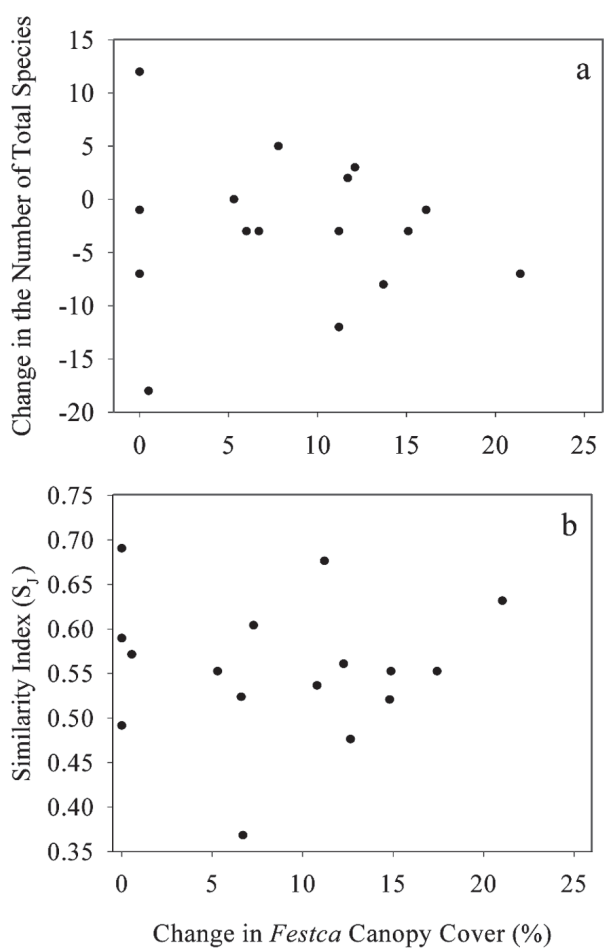

Fig. 5a. Change in Festuca canopy cover against change in the number of total species on 16 study plots from 1999 to 2001 ( $P$ $=0.76)$. b. Plot of the correlation between change in Festuca canopy cover from 1999 to 2001 and the Jaccard Similarity Index (change in species presence) $(P=0.99)$.

\section{Discussion}

We expected grazing cessation in this seral old-field grassland with Festuca arundinacea to result in community vegetation changes that follow successional patterns observed elsewhere in old-field grasslands released from heavy grazing (Engle et al. 2000). Instead, a five-fold increase in Festuca accounted for much of the post-grazing successional trajectory and also was associated with a decrease in the dominant functional group, warm-season native grasses. Species richness did not decline with increases in Festuca; rather, Festuca increased on plots with low species richness.

We observed a distinct separation in ordination space among old-field grassland plots in the three years following grazing cessation that represented increasing abundance of Festuca over time. On plots in which Festuca cover exceeded $10 \%$, Festuca increased by replacing warm-season native grasses, which ordinarily dominate post-disturbance succession in mid-continental warmseason grasslands (Collins \& Steinauer 1998). Our findings contrast with other tall-grass prairie studies, where, in the absence of an invasive transformer, vegetation changes within native grassland plots over a 3-yr period are chronosequences from early- to late-successional 
species (Collins \& Adams 1983; Engle et al. 2000). In our plots, successional dynamics, in terms of functional group dominance but not in terms of species richness, are explained by increasing abundance of Festuca rather than by increasing mid- and late-successional warm-season native grasses.

Unlike temperate mesic grasslands, species richness was not correlated to litter accumulation in this old-field grassland, nor did species richness decline with increasing abundance of Festuca. Our study provides an exception to numerous observations that accumulation of litter in the absence of disturbance reduces species richness in temperate mesic grasslands in North America (Knapp \& Seastedt 1986; Carson \& Peterson 1990; Facelli \& Pickett 1991; Foster \& Gross 1998). Because the absence of disturbance promotes litter accumulation, one would expect an increase in litter mass over time and a decline in species richness with cessation of grazing. However, the presence of Festuca may alter the long-term relationship between litter and species richness. Festuca has high litter quality, including rapid decomposition and reduced litter accumulation (Wieder et al. 1983). Therefore, an increase in Festuca may reduce accumulated litter mass compared to mesic grasslands with no Festuca.

Even though canopy cover of Festuca was low, we predicted its abundance to be negatively correlated with species richness in this old-field grassland dominated by warm-season native grasses. However, Festuca did not influence species richness. Rather, Festuca became more abundant on species-poor plots than on species-rich plots. Therefore, although Festuca canopy cover increased on some plots, mean Festuca abundance remained low throughout the study and a causal relationship was not detected between Festuca canopy cover and species richness. Our results contrast to studies in which Festuca, as the dominant vegetation component, influenced vegetation dynamics by decreasing species richness (Clay \& Holah 1999) and by decreasing litter accumulation (Wieder et al. 1983).

In other ecosystems where exotic species can become dominant, the exotics change community composition and alter ecosystem properties (Masters \& Sheley 2001). Our observations suggest that the short-term response of Festuca to grazing release may be a previously unrecognized parallel in some respects to that of Bromus tectorum in the Intermountain region of the western US (DiTomaso 2000; Belnap \& Phillips 2001; Masters \& Sheley 2001) and B. inermis in northern latitudes (Bragg 1995; Bowles et al.2003). B.tectorum invades and spreads rapidly, altering community composition and historic fire regimes. $B$. tectorum produces more litter and provides more fuel compared to native grasses and shrubs, thus increasing fire frequency (D'Antonio \& Vitousek 1992; DiTomaso 2000). In the northern mesic prairie, $B$. inermis increases when fire is absent, whereas both cool- and warm-season native grasses decrease. The shift in the plant community from native grasses to $B$. inermis is associated with a decline in species richness (Bowles et al. 2003).

In our study, Festuca did not reduce species richness, but Festuca dominated the successional trajectory, which is consistent with Festuca functioning as an invasivetransformer species by exerting clear ecosystem impacts (Richardson et al.2000). In manipulated grasslands seeded to Festuca, Festuca exerts even greater influence as an invasive-transformer species by reducing litter accumulation (Wieder et al. 1983), reducing species richness (Clay \& Holah 1999), and altering nitrogen dynamics through greater uptake of nitrate nitrogen than native warm-season grasses (Gay et al. 1996). Our conclusions are based on short-term change following cessation of heavy grazing, but if Festuca continues to increase in our study old-field grassland, we expect it ultimately to influence ecosystem function similar to that in monocultures and simple mixtures of Festuca. The potential consequences of Festuca invasion in the southern grassland region dominated by native warm-season grasses are striking given these grasslands, unlike their more northern counterparts (e.g. $B$. inermis invasion), have not yet experienced significant invasion by cool-season grass species.

Acknowledgements. We thank Sam Fuhlendorf and Mike Palmer for their review of the manuscript. This project was funded by the US Environmental Protection Agency through its Office of Research and Development and through an interagency agreement with the Biological Resources Division of the US Geological Survey and was administered by the Oklahoma Cooperative Fish and Wildlife Research Unit (Oklahoma State University, Oklahoma Department of Wildlife Conservation, US Geological Survey, and Wildlife Management Institute cooperating). It has not been subjected to US Environmental Protection Agency review and therefore does not necessarily reflect the views of the Agency, and no official endorsement should be inferred. The manuscript has been approved for publication by the Director of the Oklahoma Agricultural Experiment Station.

\section{References}

Anon. 1973. Soil survey of Pontotoc County, Oklahoma.USDA Soil Conserv. Serv., Washington, DC, US.

Anon. (Great Plains Flora Association) 1986. Flora of the Great Plains. University Press of Kansas, Lawrence, KS, US.

Anon. 1991. SAS system for regression, 2nd.ed. SAS Institute, Cary, NC, US.

Anon. 2000. Climatological data annual summary. National Oceanic and Atmospheric Administration, National Climatic Center, Asheville, NC, US.

Bacon, C.W. 1995. Toxic endophyte-infected tall fescue and range grasses: historic perspectives. J. Anim. Sci. 73: 861870 .

Ball, D.M., Pedersen, J.F. \& Lacefield, G.D. 1993. The tall- 
fescue endophyte. Am. Sci. 81: 370-379.

Belnap, J. \& Phillips, S.L. 2001. Soil biota in an ungrazed grassland: response to annual grass (Bromus tectorum) invasion. Ecol. Appl. 11: 1261-1275.

Bowles, M.L., Jones M.D. \& McBride, J.L. 2003. Twentyyear changes in burned and unburned sand prairie remnants in northwestern Illinois and implications for management. Am. Midl. Nat. 149: 35-45.

Bragg, T.B. 1995. The physical environment of Great Plains grasslands. In: Joern, A. \& Keeler, K.H. (eds.) The changing prairie: North American grasslands, pp. 49-81. Oxford University Press, Oxford, UK.

Carson, W.P. \& Peterson, C.J. 1990. The role of litter in a oldfield community: impact of litter quantity in different seasons on plant species richness and abundance. Oecologia 85: $8-13$

Clay, K. 1990. Comparative demography of three graminoides infected by systemic, clavicipitaceous fungi. Ecology 71 : 558-570.

Clay, K. \& Holah, J. 1999. Fungal endophyte symbiosis and plant diversity in successional fields. Science 285: 17421744.

Collins, S.L. 1987. Interaction of disturbances in tallgrass prairie: a field experiment. Ecology 68: 1243-1250.

Collins, S.L. \& Adams, D.E. 1983. Succession in grasslands: thirty-two years of change in a central Oklahoma tallgrass prairie. Vegetatio 51: 181-190.

Collins, S.L. \& Steinauer, E.M. 1998. Disturbance, diversity, and species interactions in tallgrass prairie. In: Knapp, A.K., Briggs, J.M., Hartnett, D.C. \& Collins, S.L. (eds.) Grassland dynamics: long-term ecological research in tallgrass prairie, pp. 140-156. Oxford University Press, Oxford, UK.

D'Antonio, C.M. \& Vitousek, P.M. 1992. Biological invasions by exotic grasses, the grass/fire cycle, and global change. Annu. Rev. Ecol. Syst. 23: 63-87.

Daubenmire, R.F. 1959. A canopy-coverage method of vegetational analysis. Northwest Sci. 33: 43-64.

DiTomaso, J.M. 2000. Invasive weeds in rangelands: species, impacts, and management. Weed Sci. 48: 255-265.

Engle, D.M., Palmer, M.W., Crockett, J.S., Mitchell, R.L. \& Stevens, R. 2000. Influence of late season fire on early successional vegetation of an Oklahoma prairie. J. Veg. Sci. 11: 135-144.

Facelli, J.M. \& Pickett, S.T.A. 1991. Plant litter: its dynamics and effects on plant community structure. Bot.Rev. 57: 132.

Fike, J. \& Niering, W.A. 1999. Four decades of old field vegetation development and the role of Celastrus orbiculatus in the northeastern United States. J. Veg. Sci. 10: 483-492.

Foster, B.L. \& Gross, K.L. 1998. Species richness in a successional grassland: effects of nitrogen enrichment and plant litter. Ecology 79: 2593-2602.

Freeman, C.C. 1998. The flora of Konza Prairie: a historical review and contemporary patterns. In: Knapp, A.K., Briggs, J.M., Hartnett, D.C. \& Collins, S.L. (eds.) Grassland dynamics: long-term ecological research in tallgrass prairie, pp. 69-80. Oxford University Press, Oxford, UK.

Gay, D.L., Allen, E.R., Engle, D.M. \& Stritzke, J.F. 1996. Nitrate dynamics following brush control in a post oak- blackjack oak forest. Agron. J. 88: 536-540

Gibson, D.J. \& Newman, J.A. 2001. Festuca arundinacea Schreber (F.elatior L. ssp. arundinacea (Schreber) Hackel. J. Ecol. 89: 304-324.

Hatch, S.L. \& Pluhar, J. 1993. Texas range plants. Texas A\&M University Press, College Station, TX, US.

Hoveland, C.S. 1993. Importance and economic significance of the Acremonium endophytes to performance of animals and grass plant. Agric. Ecosyst. Environ. 44: 3-12.

Inoyue, R.S., Huntly, N.J., Tilman, D., Tester, J.R., Stillwell, M.A. \& Zinnel, K.C. 1987. Old field succession on a Minnesota sand plain. Ecology 68: 12-26.

Jongman, R.H.G., ter Braak, C.J.F. \& van Tongeren, O.F.R. 1995. Data analysis in community and landscape ecology. Cambridge University Press, Cambridge, UK.

Knapp, A.K. \& Seastedt, T.R. 1986. Detritus accumulation limits productivity of tallgrass prairie. BioScience 36 : 662-668.

Knapp, A.K., Briggs, J.M., Blair, J.M. \& Turner, C.L. 1998. Patterns and controls of aboveground net primary production in tallgrass prairie. In: Knapp, A.K., Briggs, J.M., Hartnett, D.C. \& Collins, S.L. (eds.) Grassland dynamics: long-term ecological research in tallgrass prairie, pp. 193-221. Oxford University Press, Oxford, UK.

Masters, R.A. \& Sheley, R.L. 2001. Principles and practices for managing rangeland invasive plants. J. Range Manage. 54: 502-517.

Matthews, J.W. \& Clay, K. 2001. Influence of fungal endophyte infection on plant-soil feedback and community interactions. Ecology 82: 500-509.

Richardson, D.M., Pysek, P., Rejmánek, M., Barbour, M.G., Panetta, F.D. \& West, C.J. 2000. Naturalization and invasion of alien plants: concepts and definitions. Divers. Distrib. 6: 93-107.

Smith, M.D. \& Knapp, A.K. 1999. Exotic plant species in a $\mathrm{C}_{4}$-dominated grassland: invasibility, disturbance, and community structure. Oecologia 120: 605-612.

Stubbendieck, J., Hatch, S.L. \& Butterfield, C.H. 1997. North American Range Plants. University of Nebraska Press, Lincoln, NE, US.

ter Braak, C.J.F. \& Šmilauer, P. 1998. CANOCO reference manual and user's guide to Canoco for Windows: Software for canonical community ordination (version 4). Microcomputer Power, Ithaca, NY, US.

Tremmel, D.C. \& Peterson, K.M. 1983. Competitive subordination of a Piedmont old field successional dominant by an introduced species. Am. J. Bot. 70: 1125-1132.

Waller, S.S. \& Lewis, J.K. 1979. Occurrence of $\mathrm{C}_{3}$ and $\mathrm{C}_{4}$ photosynthetic pathways in North American grasses. $J$. Range Manage. 32: 12-28.

Weaver, J.E. 1968. North American Prairie. University of Nebraska Press, Lincoln, NE, US.

Wieder, R.K., Carrel, J.E., Rapp, J.K. \& Kucera, C.L. 1983. Decomposition of tall fescue (Festuca elatior var. arundinacea) and cellulose litter on surface mines and a tallgrass prairie in central Missouri, USA.J.Appl.Ecol.20: 303-321.

Received 22 May 2002; Accepted 4 February 2004. Co-ordinating Editor: B. Collins. 